\title{
Incidental capture of seabirds in the New Zealand subantarctic squid trawl fishery, 1990
}

\author{
J. A. BARTLE
}

\section{Summary}

Fisheries observers recorded incidental capture of seabirds during 338 days on Soviet squid trawlers in New Zealand subantarctic shelf waters around the Snares and Auckland Islands in 1990. Seven species were recorded entangled in fishing gear, including very high numbers of breeding adult White-capped Albatrosses Diomedea cauta steadi. The actual level of White-capped Albatross mortality was estimated at 2,300 birds in 1990, and is not considered sustainable. Nearly all albatrosses were killed by collision with the netsonde monitor cable. In New Zealand waters this equipment is carried only by Soviet trawlers, and is considered obsolete. Replacement of this cable by discrete netsonde transducers on Soviet trawlers should be a global seabird conservation priority.

\section{Introduction}

Since the late 1970 s large mid-water trawlers have fished for squid (primarily arrow squid Notodarus sloanii) over shelf and slope waters around the subantarctic islands of New Zealand. Trawling now occurs between December and May, and from 8,000 to 39,000 tonnes per year (Annala 1991) are caught by the fleet of around 50 vessels. Most Soviet trawlers in the fishery are part of the Far East Fishing Fleet, based at Nakhodka. They range in size from 1,898 to 4,407 gross registered tonnes (g.r.t.), but most are of the Atlantic Class, 2,099 g.r.t.

Following the establishment of an Exclusive Economic Zone out to 200 miles from these islands in 1978, increasing numbers of the Soviet vessels in the fishery have been operated under charter to New Zealand companies. Since 1986 the New Zealand Ministry of Agriculture and Fisheries (MAF) has required some of these vessels to carry New Zealand fisheries observers. The primary purpose of the Scientific Observer Programme is to monitor compliance with the New Zealand fisheries regulations and to collect information for stock assessment. However, following reports (and samples) of large kills of White-capped Albatrosses Diomedea cauta steadi from Soviet vessels in the squid trawl fishery in 1988 and 1989, MAF fisheries observers were asked to record information on incidental capture of seabirds on a systematic basis.

In 1990 observed Soviet squid trawlers fished from the Snares Shelf at $48^{\circ} 40^{\prime} S$ southward past the Auckland Islands to $51^{\circ} 30^{\prime} S$. As in the past (Donoghue 1985), most trawling was done within 60 miles of the Auckland Islands, where there are large breeding colonies of seabirds which feed in great numbers over the surrounding shelves. Seabirds, and especially albatrosses, naturally scavenge for dead squid at the sea surface (Lipinski and Jackson 1989), and 
several species have learnt to recognize trawlers and to specialize in scavenging trawl waste (Bartle 1974). The best time for seabirds to obtain food from trawlers is when the net is being hauled, or as waste is being discharged from the factory. At such times birds come close to the vessel and may collide with projecting structures or become entangled in trawl gear.

\section{Data collection}

Full reports were received from 11 MAF fisheries observers who collected seabird data from four vessels over 338 days fishing, by monitoring 897 tows over the period January-April 1990, as detailed in Tables 1 and 2 (a tow is the operation of towing the trawl net behind the vessel from the time of launching the net down the stern ramp to hauling the catch on board). Observers recorded the number of each seabird species snagged on the netsonde monitor cable (which connects the echosounder on the headline of the trawl net to the vessel, allowing the trawlmaster to see where the net is from the bridge) and entangled in the net and fishing gear. These counts were made as the gear was being hauled aboard, and did not take into account birds which might have been killed or injured by collision with the equipment and been lost. Sometimes observers relied on crew members to retrieve birds from the netsonde cable or net, but this was not always done. The effect of these cumulative sampling errors results in underestimation of true kill and injury rates.

Dates, positions of shooting and hauling, tow number, and weather were also recorded. Large samples of birds were frozen and returned to the National Museum of New Zealand for verification of identification and autopsy. Observers were asked to suggest ways in which incidental mortality of seabirds could be reduced or avoided, and several discussed their observations with

Table 1. Data sources

\begin{tabular}{lcr}
\hline Dates & Tows & $\begin{array}{c}\text { No. White-capped } \\
\text { Albatrosses caught }\end{array}$ \\
\hline $31.12 .89-30.03 .90$ & 237 & 72 \\
$7.01 .90-12.02 .90$ & 125 & 36 \\
$15.01 .90-24.04 .90$ & 240 & 100 \\
$30.01 .90-23.02 .90$ & 73 & 8 \\
$28.02 .90-24.03 .90$ & 70 & 5 \\
$17.02 .90-25.04 .90$ & 152 & 15 \\
\hline
\end{tabular}

Table 2. Birds caught by four squid trawlers, 1990

\begin{tabular}{lr}
\hline Species & Number \\
\hline Royal Albatross Diomedea e. epomophora & 1 \\
Grey-headed Albatross Diomedea chrysostoma & 3 \\
Buller's Albatross Diomedea b. bulleri & 3 \\
White-capped Albatross D. cauta steadi & 236 \\
White-chinned PetreI Procellaria aequinoctialis & 2 \\
Sooty Shearwater Puffinus griseus & 30 \\
Prion Pachyptila sp. & 4 \\
\hline
\end{tabular}


trawlmasters at sea. Their suggestions have been incorporated into this paper. Anonymity of observers and vessels has been preserved at the request of MAF. Seabird nomenclature follows CCOSNZ (1990).

\section{Results}

\section{Species composition}

Altogether 279 seabirds of seven species were caught (Table 2). Except for Whitecapped Albatrosses and, to a far lesser degree, Sooty Shearwaters Puffinus griseus, a superabundant species (Warham and Wilson 1982) not thought to be much affected by such mortality, none was caught frequently enough to be a problem. The remainder of this report is therefore solely concerned with the White-capped Albatross.

\section{Observed kill rates}

In 1990 the 27 Soviet trawlers which participated in the subantarctic squid fishery made 4,349 net tows (MAF Fisheries Communication Centre unpublished data). Multiplying this latter figure by the mean kill rate of 0.263 birds/tow (Table 3) gives a minimum estimate of the number of White-capped Albatrosses killed in this fishery in 1990 of 1,144 birds.

Recorded rates of capture (Table 3) varied nearly fivefold between vessels, from an average of 0.09 birds/tow to 0.42 birds/tow. Fishermen did not always cooperate with observers in counting and retaining albatross corpses, and so much of the variation in the recorded rate of capture is probably due to sampling error. Even the highest figure ( 0.42 birds/tow) is substantially underestimated according to direct observation. A 1989 count over a one-month period gave the highest kill - 231 White-capped Albatrosses in a 30-day period, an average of 7.7 birds/day, eleven times as high as the average (o.698 birds/day) recorded in 1990.

\section{Error correction}

Thus, although undercounting of albatross by-catch was certainly established in a few instances, because observer error was unmeasured, it is difficult to correct for. A realistic figure for overall mortality must somehow compensate for undercounting, corpses lost from the netsonde cable and not swept up by the trawl net, and for birds which die as a result of injuries but are not entangled in trawl gear and recovered. Therefore, to estimate the effect of incidental mortality on

Table 3. Mean kill rates of White-capped Albatrosses in the squid trawl fishery, 1990

\footnotetext{
13 albatrosses in 143 tows $=0.09$ birds/tow 15 albatrosses in 152 tows $=0.10$ birds/tow 72 albatrosses in 237 tows $=0.30$ birds/tow 100 albatrosses in 240 tows $=0.42$ birds/tow 36 albatrosses in 125 tows $=0.29$ birds $/$ tow Mean kill rate $=0.263$ birds $/$ tow .
} 
the breeding population of White-capped Albatrosses, the observed kill rate of 1,144 birds has been simply doubled to 2,300 to provide a more reliable estimate of by-catch mortality within wide confidence limits.

\section{Autopsy results}

Of the 35 White-capped Albatrosses from the 1990 season autopsied at the National Museum, all were breeding adults, as determined by gonadal development. There was no significant bias in sex ratio (19 males; 16 females). This differs from the situation with tuna longlines, where female Wandering Albatrosses Diomedea exulans and Grey Petrels Procellaria cinerea are far more often caught than are males (Weimerskirch and Jouventin 1987, Bartle 1990, Croxall and Prince 1990).

All White-capped Albatrosses autopsied were in healthy condition, and often quite fat. Cause of death appeared to have been drowning, mostly associated with fresh serious injuries (broken wings, legs, bills, etc.) in conformity with having collided with and become entangled in trawl gear.

\section{Causes of mortality}

The section of trawl gear in which White-capped Albatrosses were entangled was systematically recorded in 1990. In 177 cases the birds were either caught on the netsonde monitor cable or had injuries showing that this had happened. Of the remaining 37 for which the position of entanglement was recorded, six were caught in the headline itself, 12 had drowned in the net wings, and 19 were entangled with the bellylines (many of these had probably fallen off the monitor wire). Thus at least $83 \%$ and probably nearer $92 \%$ of White-capped Albatrosses were killed by collision with the netsonde monitor cable.

The headline netsonde monitor cable extends from the top of the aft gantry up to $20 \mathrm{~m}$ behind the vessel. The cable is $7 \mathrm{~mm}$ in diameter and very stiff because it contains insulated wires, and thus it whips up and down as the vessel pitches in the swell. It is grey, and very hard to see on overcast days and in twilight. Albatrosses feeding behind trawlers have their eyes set on offal and, as their low-light vision is probably little better than humans (cf. Brooke 1989) they fail to see the monitor cable and crash into it. This situation is exacerbated when trawl waste is being discharged and is churned up in the wake by turbulence. Birds criss-crossing the wake have to cross the flexing monitor cable en route to the upwelling offal. In attempting to do this they hit the cable.

The number of birds that collide with the monitor cable is very high, and it is likely that many more are killed and injured than are subsequently recovered when the net is hauled aboard. In 1989 one observer estimated that fewer than half of the birds killed by collision with the monitor cable are recovered from the net. Two 15-minute counts illustrate the problem (4 February 1990, o6h20-o6h35, o6h5o-o ho5; position $50^{\circ} 15^{\prime} \mathrm{S} 166^{\circ} 19^{\prime} \mathrm{E}$; wind $6 \mathrm{~m} / \mathrm{sec}$; visibility poor). During the first 15-minute count 13 White-capped Albatrosses and one Sooty Shearwater hit the monitor cable, and there were many near-misses. None of these birds was killed. During the second period four White-capped Albatrosses and one Sooty Shearwater hit the cable with, again, no kills. One dead White-capped Albatross was subsequently (oghio) recovered when the net was hauled. 
Albatrosses which are killed by the monitor wire are generally wrapped around it with a broken, or even torn-off wing. They also get snagged on stiff broken strands which are common on worn parts of the monitor cable. Albatross carcasses which do not get snagged or washed off slide down the stiff monitor wire like oceanographic messenger weights, accumulating in clumps at a joint just above the headline monitor itself. Others drop back into the bellylines when the net is hauled, as a result of turbulence around the headline. Such birds can be identified by their wing injuries. Further corpses drop off the wire earlier, as indicated by the odd feather on the monitor cable even when no albatrosses are hauled aboard with the net, and yet more are seen falling from the monitor wire as it passes over the gantry during hauling.

A much smaller number of albatrosses are caught in the belly of the net while taking squid during hauling and are drowned. Others have been found caught in the headline and bellylines. Two observers recorded $60 \%$ of albatrosses killed as being entangled in the net rather than on the monitor wire, but perhaps these had been washed off.

\section{Factors influencing kill rates}

Albatrosses are not caught regularly and, in most tows, none was caught (Table 4). Of the birds recovered, $64 \%$ were caught at a rate equal to or greater than three birds per tow (Table 4). This, combined with the fact that very large numbers of birds may be caught in some tows, suggests that weather could play a part in the birds' entanglement. When weather was recorded for these large catches, it was most often overcast, calm and sometimes foggy $(n=10)$, but sometimes rainy (2) or stormy (3). Adverse weather probably increases incidental capture of albatrosses in three ways:

(i) by reducing visibility of the monitor cable;

Table 4. Rate of capture

\begin{tabular}{ccc}
\hline No. of albatrosses & $\begin{array}{c}\text { No. of hauls with this } \\
\text { no. of albatrosses }\end{array}$ & $\begin{array}{c}\text { \% distribution of } \\
\text { birds caught }\end{array}$ \\
\hline 1 & 37 1+ & 0.0 \\
2 & 37 & 14.8 \\
3 & 27 & 21.6 \\
4 & 8 & 9.6 \\
5 & 4 & 6.4 \\
6 & 4 & 8.0 \\
7 & 1 & 2.4 \\
8 & 3 & 8.4 \\
9 & 1 & 3.2 \\
10 & 0 & 0.0 \\
11 & 0 & 0.0 \\
12 & 2 & 8.8 \\
13 & 1 & 4.8 \\
14 & 1 & 5.2 \\
15 & 0 & 0.0 \\
16 & 0 & 0.0 \\
17 & 0 & 0.0 \\
& 1 & 6.8
\end{tabular}


(ii) by increasing the flex in the monitor cable; and

(iii) by increasing the need for albatrosses to scavenge (hunger).

\section{Discussion}

Status, abundance, and likely normal adult survival rates of the New Zealand Whitecapped Albatross

A revision of albatross systematics by C. J. Robertson (unpublished) has revealed major morphological, behavioural and ecological differences between the three previously recognized forms of Shy Albatross (D. c. cauta, D. c. salvini, and $D$. c . eremita) showing that they are different, though related, species. Robertson (unpublished) has also confirmed that the New Zealand population of the White-capped Albatross (D. cauta steadi) is subspecifically distinct from the nominate Tasmanian race, with differences in morphology, behaviour and ecology. All the White-capped Albatrosses killed in this fishery have apparently been of the subspecies Diomedea cauta steadi Falla 1933, which is confined to the Auckland Islands for breeding.

Feral pigs have greatly reduced the White-capped Albatross colony on the main Auckland Island (Robertson and Jenkins 1986), leaving the birds essentially confined to a single large colony $(60,000$ pairs $\pm 10 \%$, Robertson 1975$)$ on Disappointment Island, plus a few (200 pairs \pm ) on Adams Island. Observations (C. J. Robertson pers. comm.; J. A. Bartle unpublished) suggest that these numbers were fairly stable during the period 1973-1981.

No information on breeding frequency or survival is available for New Zealand White-capped Albatrosses. As these data are essential for precise assessment of the impact of by-catch mortality on the population, figures have been extrapolated from studies on related species. All ocean-front or shelf-feeding albatrosses for which data are available (Black-browed D. melanophrys, Yellownosed $D$. chlororhynchos and Buller's $D$. bulleri) breed every year (Weimerskirch et al. 1987). As D. cauta and its relatives are shelf-feeding specialists (Bartle 1974 and unpublished), it seems fairly safe to assume that they breed annually, in contrast to other smaller southern albatrosses which are off-shelf (pelagic) foragers (Grey-headed D. chrysostoma, Sooty Phoebetria fusca and Light-mantled Sooty $P$. palpebrata) and breed biennially. Using large samples and long timeseries (up to 30 years), Weimerskirch et al. (1987) found that mean annual survival varied from 0.912 in the smallest to 0.968 in the largest of five albatross species in the Indian Ocean. Depressed survival rates of 0.881 and 0.909 were associated with fishery by-catch problems.

Thus, in summary, the world breeding population of New Zealand Whitecapped Albatrosses is probably about 120,00o birds, mostly confined to Disappointment Island. It is likely that these breed annually with a natural adult survival rate of between 0.90 and 0.95 .

Distribution and numbers of White-capped Albatrosses on the trawling grounds (vulnerability)

White-capped Albatrosses are essentially birds of the continental shelf and are preferential scavengers behind trawlers (Bartle 1974). They are by far the most 
abundant albatross on the Auckland Islands Shelf (J. A. Bartle unpublished data; MAF fisheries observers pers. comm.), with flocks of 2,000-3,000 birds commonly associated with the fishing fleet (Robertson and Jenkins 1986). High frequency of capture in this fishery thus simply reflects their abundance and tendency to scavenge close to trawlers. It is probable that, in summer, a large proportion of the breeding population from Disappointment Island feeds on the shelf and shelf-break around the Auckland Islands, rather than far away, like Light-mantled Sooty or Grey-headed Albatrosses (Weimerskirch et al. 1986).

\section{Effect of by-catch mortality on the breeding population}

With a breeding population of 120,000 birds, normal mortality rate of 0.90-0.95, and a by-catch of 2,300 birds, the increase in adult mortality of White-capped Albatrosses is close to $2 \%$. For Wandering Albatrosses, Croxall et al. (1990) have shown that an increase in mean annual adult mortality of this level has been enough to cause their population to decline on South Georgia. Using demographic models devised by Leslie $(1945,1966)$, it can be shown that neither an advance in age at first breeding nor an increase in the percentage of Wandering Albatrosses breeding each year can compensate for increased adult mortality (Weimerskirch et al. 1987). If breeding adult mortality occurs during nesting, then it will also involve the loss of an egg or chick, thus exacerbating the impact on population size. Recent studies brought together by Newton (1989) show that in all bird species most progeny are produced by a small percentage of adults. Thus accelerated adult mortality at the level reported here will likely result in the decline of the White-capped Albatross.

\section{Duration and extent of mortality}

Seabird capture rates, specimens, and anecdotal information from previous years (1988 and 1989) suggest that mortality rates in 1990 were generally representative. However, during the 1990 season less trawling was done $(5,284$ tows, all vessels combined) than in earlier years (mean number of tows 19791983 8,933: Doonan and Cawthorn 1984). Reduced bird capture rates in 1991, when the fishery was largely based around the Snares Islands and few squid were caught (MAF unpublished data), suggest that kills of White-capped Albatrosses are highest when trawlers concentrate on the Auckland Islands Shelf.

The White-capped Albatross population also sustains accelerated adult mortality from capture on bluefin tuna longlines. In Australian (Brothers 1991) and New Zealand waters (J. A. Bartle unpublished) they are commonly caught, though the numbers killed are probably fewer than in the subantarctic squid trawl fishery.

\section{Wider implications and possible solutions}

High numbers of seabirds entangled in trawl gear have been recorded only from Soviet vessels. Fisheries observers on New Zealand, Japanese, Korean and other trawlers have not reported significant seabird by-catch. In this study, nearly all albatross mortality was caused by collision with the netsonde monitor cable. 
This equipment is used in New Zealand waters only by Soviet vessels. Large modern trawlers of other nations either use hull-mounted transducers or tow aquaplanes on which transducers are set.

Preliminary data from other fisheries in New Zealand and elsewhere in which Soviet trawlers are involved suggest that netsonde cables cause significant albatross and petrel mortality wherever they are used on shelf areas where seabirds concentrate. In the New Zealand area, fisheries observers on Soviet trawlers fishing for Hoki Macruronus novaezelandiae in the Puysegur Trough $\left(47^{\circ} \mathrm{S}\right.$, west of Stewart Island) reported substantial mortality of albatrosses in 1989 and 1991, especially of the relatively rare Buller's Albatross. Elsewhere in the Southern Ocean, high numbers of Black-browed Albatrosses and Whitechinned Petrels Procellaria aequinoctialis are killed by Soviet trawlers on the Kerguelen Shelf (Weimerskirch et al. 1987, 1989). Soviet trawlmasters also mentioned to New Zealand fisheries observers massive mortality of seabirds through collision with netsonde cables in the Sea of Okhotsk. Thus there is evidence to suggest that use of obsolete netsonde cables by Soviet trawlers is an international issue in seabird conservation.

The hard-currency crisis in the Soviet Union discourages replacement of netsonde cables by discrete transducers, placing government agencies responsible for fisheries management in an awkward position. The onus is now on governments and the fishing industry rapidly to implement solutions to this relatively straightforward problem. Where Soviet trawlers are operated under charter to the companies of other nations, then clearly those companies have the responsibility to provide the necessary funds.

\section{Acknowledgements}

This report was entirely based on the hard work of the MAF Fisheries Scientific Observer Programme coordinated by Janice Denney. I am indebted to the observers involved and to Noel Hyde (National Museum) for autopsy of the samples. Alan Tennyson (Royal Forest and Bird Protection Society), Jean-Claude Stahl (Victoria University of Wellington), Don Robertson and Rob Mattlin (MAF Fisheries) kindly provided information and suggestions which improved the manuscript.

\section{References}

Annala, J. H., compiler (1991) Report from the Fishery Assessment Plenary, April-May 1991. Stock assessment and yield estimates. Wellington, N.Z.: MAF Fisheries, unpublished report.

Bartle, J. A. (1974) Seabirds of eastern Cook Strait, New Zealand, in autumn. Notornis 21: $135-166$.

Bartle, J. A. (1990) Sexual segregation of foraging zones in procellariiform birds: implications of accidental capture on commercial fishery longlines of Grey Petrels (Procellaria cinerea). Notornis 37: 146-150.

Brooke, M. L. (1989) Determination of the absolute visual threshold of a nocturnal seabird, the Common Diving Petrel Pelecanoides urinatrix. Ibis 131: 290-294.

Brothers, N. (1991) Albatross mortality and associated bait loss in the Japanese longline fishery in the Southern Ocean. Biol. Conserv. 55: 255-268. 
$\mathrm{CCOSNZ}=$ Checklist Committee, Ornithological Society of New Zealand (1990) Checklist of the birds of New Zealand. Auckland: Random Century.

Croxall, J. P. and Prince, P. A. (1990) Recoveries of Wandering Albatrosses Diomedea exulans ringed at South Georgia 1958-1986. Ringing and Migration 11: 43-51.

Croxall, J. P., Rothery, P., Pickering, S. P. C. and Prince, P. A. (1990) Reproductive performance, recruitment and survival of Wandering Albatrosses Diomedea exulans at Bird Island, South Georgia. J. Anim. Ecol. 59: 775-796.

Donoghue, M. F. (1985) Final report on status of Hooker's Sealion and incidental catch in the Auckland Islands squid fishery. WWF-IUCN Project No. 3618. Unpublished report.

Doonan, I. J. and Cawthorn, M. W. (1984) Impact of incidental mortality on the Hooker's Sea Lion. MAF Fisheries Research Centre Internal Report No. 6.

Leslie, P. H. (1945) On the use of matrices in certain population mathematics. Biometrika 33: 183-212.

Leslie, P. H. (1966) The intrinsic rate of increase and the overlap of successive generations in a population of guillemots (Uria aalge). J. Anim. Ecol. 25: 291-301.

Lipinski, M. R. and Jackson, S. (1989) Surface-feeding on cephalopods by procellariiform seabirds in the southern Benguela region, South Africa. J. Zool. 218: 549-563.

Newton, I., ed. (1989) Lifetime reproduction in birds. London: Academic Press.

Robertson, C. J. (1975) Report on the distribution, status and breeding biology of the Royal Albatross, Wandering Albatross and White-capped Mollymawk on the Auckland Islands. Pp.143-152 in J. C. Yaldwyn, ed. Preliminary results of the Auckland Islands Expedition 1972-1973. Wellington: Department of Lands and Survey.

Robertson, C. J. and Jenkins, J. (1986) Bird observations, Auckland Islands, FebruaryJune 1981. Pp.70-77 in A. Penniket et al. (compilers) Preliminary reports of expeditions to the Auckland Islands Nature Reserve 1973-1984. Wellington: Department of Lands and Survey.

Warham, J. and Wilson, G. J. (1982) The size of the Sooty Shearwater population at the Snares Islands, New Zealand. Notornis 29: 23-30.

Weimerskirch, H., Clobert, J. and Jouventin, P. (1987) Survival in five southern albatrosses and its relationship with their life history. J. Anim. Ecol. 56: 1043-1055.

Weimerskirch, H. and Jouventin, P. (1987) Population dynamics of the Wandering Albatross, Diomedea exulans, of the Crozet Islands: causes and consequences of the population decline. Oikos 49: 315-322.

Weimerskirch, H., Jouventin, P. and Stahl, J.-C. (1986) Comparative ecology of the six albatross species breeding on the Crozet Islands. Ibis 128: 195-213.

Weimerskirch, H., Zotier, R. and Jouventin, P. (1989) The avifauna of the Kerguelen Islands. Emu 89: 15-29.

J. A. (Sandy) BARTLE

National Museum of New Zealand, P.O. Box 467, Wellington, New Zealand. 